Ayurlog: National Journal of Research in Ayurved Science http://www.ayurlog.com Volume: $6^{\text {th }} \mid$ Issue: $5^{\text {th }} \mid$ August 2018

\title{
Swarna Prashana Samskar In Ayurveda-a critical review
}

\section{Nishad Prashant**1, Bhonsle Amiya ${ }^{2}$, Chandrakar Anchal ${ }^{3}$}

1. M.D.( Rachana Sharira), Asst. professor Dept. of Rachana Sharira, Bharti Ayurved Medical College \& Hospital, Durg, (C.G.)

2. M.D.(Panchkarma), Consultant \& Asst. professor Dept. of Panchkarma, Bharti Ayurved Medical College \& Hospital, Durg, (C.G.)

3. P.G.Scholar, Panchkarma, S.M.B.T.Ayurved College \& hospital, Nashik, (M.S.)

*Corresponding author: Email - drnishadprashant@gmail.com ; Mob. : 91-9826403234

\section{ABSTRACT}

The health promotive, disease preventive and rejuvenation approach available in the Indian system of medicine that is known as 'Ayurveda', which is gaining greater attention and popularity in many regions. of the world. Ayurvedic pharmacolog classifies medicinal plants into different groups according to their actions. One of these is the 'Rasayana'. It deals with the preservation and promotion of the health by revitalizing the metabolism and enhancing the immunity. In Kashyap samnhita sutrasthan Swarna prashana samskar is a unique method of giving swarna bhasma mixed with honey and ghrita that is fortified with herbal extract to children orally. This process promotes overall growth in a natural way. This paper deals with the process of Swarna prashan sanskara, its uses the role of the Swarna with the other drugs, ingredients in the children, and also to determinate Swarna prashana as a natural immunization process.

KEYWORDS: Ayurveda, Rasayana, Samskar, Swarna prashana Samskar

\section{INTRODUCTION}

Swarna prasahan samskar is one of the essential rituals described in Ayurveda for the children. It is the process where the purified ash of gold is administered with fortified ghrita prepared with herbal extracts and honey in liquid or semisolid form and given to the children orally. It enhances the immunity, stamina, physical and mental well being of children. It is a sacred and unique pearl of ocean of Ayurveda. Gold is considered as a auspicious metal from many years ago, while ayurveda has unique method of management to treat chronic disease and maintain the healthy condition by preventing the infection and enhancing the immunity. Swarna prasahan samskar act as natural immunization so it helps to maintain the health and disease free life span to children.

\section{AYURVED REVIEW}

Ancient pediatrician Maharshi Kashyap described Swarna prashan samskar in his valuable manuscript that is kashyap Samnhita. This samnhita specially deals with growth, disease, treatment, role of 
planets in life span of children. Maharshi Kashyap was concerned not only for children's physical stamina but also for mental stability. To fulfill above mentioned aim he discovered the Swarna prashan samskar. He describes that ${ }^{1}$ -

Suvarnprashan hietat medagni bala vardhanam.| Ayushyam mangalam punyam vrushyam grahapam.|| Maasat param medhave vyaddhirbhinn cha dhrushyate.| Shabd hirmaasai shrutdhar suvarnaprashanad bhavet. || ( K.S.S.18/4-5)

Swarna prashan samskar enhances the intelligence, physical stamina, disease free life to children. It also keeps safe children from evil effect of planets. It improves the memory and recall power that's why this process is sacred and beneficial in th present era as well. Benefits of this process are as following-

1. Increase immunity power and develops resistance against common infection.

2. Increase physical strength and growth of the children.

3. Increase grasping power, analysis power and recall property.

4. Improves digestive proper.

5. Tones up skin colour and texture.

6. Protects the children from different kind of allergies.

7. Protects children from aliments occurring during teething phase.

8. Enhance the intellectual property.(Medha)

9. Maintain digestive and metabolic property. (Agani)

10. Increase strength (Bala)
11. Longevity (Ayush)

12. Auspicious (Mangalam)

13. Vitrous (Punyam)

14. Aphrodisiac (Vrishyam)

15. Increase complexion ( Varnya)

16. Eliminates the evil effects of planets (Grahapaham)

\section{INGREDIENTS OF SWARNA}

\section{PRASAHAN -}

1. Pure ash of gold

2. Pure honey

3. Fortified herbal extract which are brain tonic like Guduchi, Mandukparni, Bramhi, Yashti madhu, Vacha etc.

\section{Ghrita}

\section{(1) FUNCTION OF GOLD ASH}

It increases intellect, digestive and metabolic power, strength, aayusha Provide longevity), increase complexion zarnaya $)^{2}$. Gold ash is also said to be vatashamaka, Rasayana, dipan, netrya, medhya ${ }^{3}$ etc.

\section{(2) FUNCTION OF HONEY}

Madhu (Honey) is sheet, guru, madhur, and kashaya by quality by action it is raktapitta and kapha nasaka as well as chhedan, ${ }^{4}$ hridya, tridoshhar ${ }^{5}$ etc.

(3) FUNCTION OF MEDHYA DRUGS

1. Guduchi- The fresh juice of Guduchi on the dose of $20 \mathrm{ml}$ twice will be the brain tonic ${ }^{6}$. (C.CHI.1/1)

2. Mandukparni- Charaka described it especially as 'Medhya Rasayana' and the same is accepted by all the Ayurvedic texts. 
3. Bramhi - Atharava parisista and other texts quote Bramhi as Medhya ${ }^{7}$. It works as kapha-pitta har, medhya and rasayana by efficacy.

4. Yashti madhu-Brahat tayi used this herb extensively in therapeutics but Charaka included it in many of his kasaya vargas. He also emphasized its utility among Rasayana drugs. Atharva Parisita described madhuka and is considered as Dourbhagyanasana and Garbhabrmhana.

5. Vacha - Sayana explained that this drug improves the intelligence and speech of an individual. ${ }^{8}$ It is one of the extensively prescribed herbs in the Brhat tayi texts. Ugragandha is the synonym used by them for once each ${ }^{9}$. The karma of this drug is Kapha-vatahara, medhya.

\section{(4) FUNCTION OF GHRITA}

According to Charaka, ghrita is useful to rasa, sshukra dhatus and oja (immunity), pittanialhara, svaravarna prashadanum. According to Sushruta Ghrita increases smriti (memory), medha (intellectual property), kaanti ( glow and aura), voice, oja, strength, vishhar, rakshoghan. ${ }^{11}$

\section{MODERN REVIEW}

Age- Swarna prasahan can be administrated from birth till 16 years. This time period is essential for physical and mental growth of children. In swarna prasahan children are administrated by pure ash of gold as an antibacterial agent, honey as an anti allergic, and fortified herbal extract which are brain tonics with ghrita, it will increase the immunity of kid, enhance growth of bones and other tissue, and maintain the homeostasis. Adolescent period is preferable time to manage the growth that's why this time period is perfect by providing acquired immunity, physical and mental stability to children.

Time- It should be administered on empty stomach, every morning or on the day of pushya nakshtara. The drop/semisolid liquid should be given by the parents to the baby in empty stomach. As per modern physiology it is proved that medicine will be absorbed properly in empty stomach. Medicine will not digest and absorb with other food material which may cause adverse effect to the children.

Day-Pushya nakshatra is considered as most auspicious among other stars, it is considered as 'The star of nourishment'. The words itself translates to nourisher or thrive. Pushya nakshatra is beneficial for-

(1) To take medicine

(2) To learn from guru

(3) To prepare herb

(4) To meet spiritual person and learning from him

(5) To learn about rituals, Veda and Aagams.

Administrating drugs on this day seem very effective in terms of action. Since Swarna prasahan's main ingredient is gold. It is an auspicious day to buy gold or to prepare, administrate the preparations of gold. The radiation and the medical potency is more in gold on this day that said to be good day to administer any type of medicine prepared by gold. Maharshi Kashyap believes that there are some gods, and evil that are represented by planets and they have their respective property and effect which will affect the children. 
Pushya nakshatra is an auspicious day in the Hindu rituals when people start worship and new venture, this day is represented by the Lotus. So according to tradition and ritual it is auspicious day to administer the Swarna prasahan samskar. As per modern science it is proved that every planet has a specific cosmic energy which will affect the every creature in the world, so it is possible that as per their calculation and knowledge the pushya nakshtra has positive cosmic energy which will stimulate positive vibes in children.

Duration- The procedure can be administered by two ways. It can be given Continue daily dose of swarna bindu prasahn for minimum one month or maximum three months. Otherwise it can be given to children once in a month for 30 months on pushya nakshtra.

Procedure- During the procedure while giving the drops, face of parent should $b$ towards north and face of children should be towards east. Ayurveda strongly prefer the importance of direction and situation of patient and doctors both because it will affect the effect of medication. North and east directions are considered as a sacred direction which will enhance the affinity of the medicine by cosmic rays.

Diet- Children should be on empty stomach for better absorption. After swallowing the swarna prashana, it will be absorbed by stomach and intestine after proper digestion. So the digestive system of children should be in proper manner. The child can be fed after 30minutes. It is better to avoid junk food on that day.

MODE OF ACTION
(1) MODE OF ACTION OF PURE GOLD ASH- It acts by scavenging effect. Swarna bhasma inhibits the numerous cell mediated immune response to various mitogen and antigen. Gold compound has immunomodulator function ${ }^{12}$. It enhances the memory, so when it is administered in very low dose for a particular time, it is known to potentiate the memory power along with immunity. Animal researches conducted on pure ash of gold showed the use of swarna bhasma in dose of 12.5 to $50 \mathrm{mg} / \mathrm{kg}$ of body weight on mice weight had a stimulatory effect on peritoneal macrophages that might be helpful to fight against infection. It is believed that macrophages achieved stimulation due to presentation of the metal to cells in fine emulsified forms.

(2) MODE OF ACTION OF BRAIN TONIC HERBS- Guduchi (Tinospora cordifolia)- It has a chemical compound tinosporin, it is a brain tonic by nature. Aqueous extract produces smooth muscle relaxation of intestine, uterus and inhibition of constrictor response of histamine and acetyl choline on smooth muscle. ${ }^{13}$ The important chemical extract of plants and their mode of action are as follows-

(1) Mandukparni

(Centella asiatica) - It has chemicals like asiatic acid, centic acid , centellic acid, centoic acid, pectic acid, carotene, centellose, hydrocotylin, asiaticsides A \& B. an antidepressant action which 
appeared to be mediated through the D2 receptor and choliomimetic action which is blocked by atropine and chlorpromazine ${ }^{14}$. It is found to posse's potent CNS depressant property. In addition it was found to possess immunomodulatory property of centella asiatica is also reported $^{15}$.

(2) Bramhi (Bacopa monnieri)- It has brahmine, herpestine, alanine, hentri-acontane, octacosane, monnierin (Saponin). These chemical extracts stimulate the central nervous system and improve the function of hypothalamus. Hersaponin was found to deplete the rat brain of its noradrenaline and 5-HT content the action being similar to tha of reserpine ${ }^{16}$.

(3) Yashti madhu (Glycyrrhiza glabra)- It have chemical extract glycyrrhizin (principal sweetening agent), glycyrrhizic acid, glycyrrhetinic acid, liquirtin, isoliquiritin, glabrine, glabranine, liquiritic acid etc.Glycyrrhizin showed antiarthritic and anti-inflammatory effect. Glycyrrhetinic acid drops were found to be of definite therapeutic value on 32 cases of allergic conguctivities both in acute and chronic cases $^{17}$.

(4) Vacha (Acorus calamus)According to modern view it have major chemical constituents like Acolamone, acorenone, acromone, acorone, calacone, calamene, calarene, eugenol, telekin etc.It inhibits the growth of $\mathrm{M}$. tuberculosis in a concentration of $10 \mathrm{mcg} / \mathrm{ml}$. It also inhibits the growth of gram negative organisms in a concentration of $0.4-0.6$ $\mathrm{mg} / \mathrm{ml}^{18}$. The extract was found to suppress the primary as well as secondary phase of inflammation significantly. It was also found as potent analgesic at a dose of 5 $\mathrm{mg} / \mathrm{kg}$. ${ }^{19}$

(3) MODE OF ACTION OF PURE HONEY-Among the allergens, pollen grains plays a major role to induce allergic reaction in children. Honey is the collection of pollen grains by bees so when honey is administered in low doses in children. The children will gradually develop resistance for allergens, also honey is immunomodulator and used as Anupana (Drink) for the better absorption of the drugs. Honey also acts as source of energy because it contains mainly fructose (About 38\%) and glucose (about $31 \%$ ) as well as vitamins and multi-minerals. Honey has antimicrobial properties and antibacterial properties against coagulate negative staphylococci. Honey has also the capacity to heal the wound.

(4) MODE OF ACTION OF MEDICATED GHRITA- Ghrita has unique property of acquiring the properties of herbs which are added to it these Nerve tonics are mandukparni (Centella asiatica), bramhi (Bacopa monneri), 
guduchi (Tinospora cordifolia), yashtimadhu (Glycyrrhiza glabra), vacha (Acorus calamus) etc. are added to ghrita and medicated ghrita is processed. This ghrita has potency to stable the mental ability, lubricating property, so results in lubrication of the mucosa of gastro intestinal tract. It also contains fat soluble vitamins such as A, D, and E. It contains saturated fatty acids but of short chain of fatty acids. This develops resistance in the body for any type of visha. In the other words it produces immunity, stamina and stability.

\section{DISCUSSION}

Ayurveda has given bunch of medical principles and effective medical treatment systems which are truly effective till now and eternal. In old era Swarna prashan would describe as a simple way inducing vaccination. Pure ash of gold improves immunity by scavenging effect; gold is very valuable metal which used for the body, mind and intelligence quality of children. Pure honey act as anti-allergic compound while herbal drugs have their specific chemical constituent which act on central nervous system, autonomic nervous system, immune system, digestive system, respiratory system etc. Ghrita enhance property of these chemical extracts by easily emulsification, lubrication and better absorption. Swarna means gold and prashana means lick. Licking of gold to children from birth to adolescent period is called Swarna prashana samskar. It acts as vaccination against different kind of diseases in children. In modern science vaccination has been discovered in early ages but Ayurveda described it many years ago. This process has scientific approach to develop acquired immunity in children, so it is a type of immunization by which children can develop a healthy, disease free, stable physical and mental life.

\section{CONCLUSION}

The process of swarna prashana is explained in the classical textbook of Ayurveda in kashyapa samnhita. Swarna is administrated with unequal amount of honey and ghrita, due to the effect of gold, honey, ghrita and herbal brain tonic drugs it act as vaccine of diverse effect and source of energy which will increase and improve the physical and mental well being. It will also develop acquired immunity which is developed due to improvement of all system of body and proper growth. Modern science is still working on vaccine which may develop Mmmity against multiple diseases this proves that Ayurveda is far developed by its unique treatment and methodology.

\section{REFERENCES}

1. Pandit Hemraj Sharma, Shri satyapal, Kashyap samnhita, kashi Sanskrit Granth mala, Varanasi, edition Third, 1998 , ( K.S.S.18/45)

2. Pandit Hemraj Sharma, Shri satyapal, Kashyap samnhita, kashi Sanskrit Granth mala, Varanasi, edition Third,1998,(K. S.L.22/12),page 4-5

3. Siddhinandan Mishra, Bhaisajyaratanavali, chaukhambha sura Bharti publication, (B.R. 2/99100), page 26.

4. Vidyadhar Shukl, Ravidatt tripathi, Charak Samnhita, Chaukhambha orientelia, Varanasi, edition 
2016,VoL II ,(C. S. S. 27/245) page 554

5. Ambika data Shastri, Sushruta Samnhita, Ayurvedtatva sandipika, (S. S. S. 45/132) page. 180.

6. Vidyadhar Shukl, Ravidatt tripathi, Charak Samnhita, Chaukhambha orientelia, Varanasi, edition 2016,VoL II (C.CHI.1/1) page 348

7. B.R.Modak,Atharava parisista, geeta press Varanasi,(A.P. 1/44/10) page 276

8. M.P. Shrivastava,Sayana, Dhanwantari publication, (2/7/1013) page 324

9. Vidyadhar Shukl, Ravidatt tripathi, Charak Samnhita, Chaukhambha orientelia, Varanasi, edition 2016, VoL II, Ambika data Shastri, Sushruta Samnhita, Ayurvedtatva sandipika, Shivsharma, Astang hridaya, Shri krishan dat publication. (C.S.Ci. 26/21; S.S.Ut 50/54 \& A.H.Ut. 39/46).

10. Vidyadhar Shukl, Ravidatt tripathi, Charak Samnhita, Chaukhambha orientelia, Varanasi, edition 2016, VoL II ( Charak samnhita sutrasthana $13 / 14$, page 258)

11. Ambika data Shastri, Sushruta Samnhita, Ayurvedtatva sandipika (S. S.Su. 45/96 ) page 177
12. Dr. J.L.N. Sastry, Dravyaguna vijnana, chaukhambha orientelia, Varanasi, edition 2016,Vol II,C.K.Hashimoto et.al. 1992, page 14.

13. ibid, Vol II, Dr. J. L. N. Sastry, Dravyaguna vijnana,Vol II, Gupta at al. 1967,

14. ibid, Vol II, Dr. J. L. N. Sastry, Dravyaguna vijnana,Vol II, page 36

15. ibid, Vol II, Dr. J. L. N. Sastry, Dravyaguna vijnana, Vol II, ( Sakina 1960 ) page 248

16. ibid, Vol II, Dr. J. L. N. Sastry, Dravyaguna vijnana, Vol II, (Plohmann et al 1994), page no 249

17. ibid, Vol II, Dr. J. L. N. Sastry, Dravyaguna vijnana,Vol II, (Malhotra et al. 1961) page no. 397

18. ibid, Vol II, Dr. J. L. N. Sastry, Dravyaguna vijnana, Vol II, ( Saxena et al. 1965) page no. 151155

19. ibid, Vol II, Dr. J. L. N. Sastry, Dravyaguna vijnana, Vol II, (Chopra et al. 1957) page no. 548.

20. ibid, Vol II, Dr. J. L. N. Sastry, Dravyaguna vijnana, Vol II, (Annual report, CCRIMH, 197778). Page no. 548

\section{Cite article}

Swarna Prashana Samskar In Ayurveda- a critical review Nishad Prashant, Bhonsle Amiya, Chandrakar Anchal Ayurlog: National Journal of Research in Ayurved Science- 2018; (6)(5) 1-7 